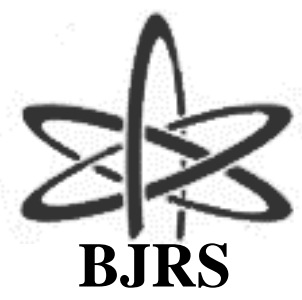

\author{
BRAZILIAN JOURNAL \\ $\mathrm{OF}$ \\ RADIATION SCIENCES \\ 09-01A (2021) 01-12
}

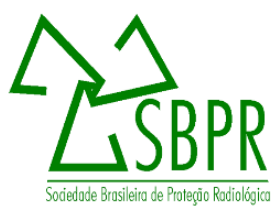

\title{
Characterization of steel slag by SEM-EDS, XRD, and
}

\author{
INAA \\ Moreira $^{a}$ D.T., Batista ${ }^{a, b}$ A.S.M., Menezes ${ }^{c}$ M.A.B.C. \\ ${ }^{a}$ Universidade Federal de Minas Gerais/Departamento de Engenharia Nuclear(DEN/UFMG) \\ Av. Antônio Carlos, 6627, CEP 31.270-901, Belo Horizonte, Minas Gerais, Brazil \\ ${ }^{b}$ Universidade Federal de Minas Gerais/Departamento de Anatomia e Imagem (IMA/UFMG) \\ Av. Alfredo Balena, 190, CEP 30.130-100, Belo Horizonte, Minas Gerais, Brazil \\ ${ }^{c}$ Centro de Desenvolvimento da Tecnologia Nuclear/Comissão Nacional de Energia Nuclear (CDTN/CNEN), Serviço \\ de Análise e Meio Ambiente, Laboratório de Ativação Neutrônica \\ Av. Antônio Carlos, 6627 Campus UFMG, CEP 31.270-901, Belo Horizonte, Minas Gerais, Brazil
}

adriananuclear@yahoo.com.br

\begin{abstract}
Steel slag is considered a by-product of the steel industry and its reuse is a strategy for environmental protection, since it consists of potential polluting materials. Besides, this material may contain chemical elements in such proportion that may be used in strategic materials such as composites and electronics. For example, magnetite $\left(\mathrm{Fe}_{3} \mathrm{O}_{4}\right)$ may be of great interest for its magnetic properties in the production of composites with different applications. On the other hand, rare earth elements (REE) production is vital for new technologies and since traces of the different REE are found in most iron ores, their extraction can be conducted together. However, previous characterization of the slag is necessary; since they vary in mineralogical composition conform to steelmaking operations. Classical characterization techniques of ores such as X-Ray Diffraction (XRD) and Scanning Electron Microscopy (SEM) may be limited to characterize small fractions of materials. Therefore, in this study, neutron activation analysis was used as the characterization technique to confirm the presence of iron and REE in the slag. The steel slag composite sample of the Linz-Donawitz (LD) process was collected in a steelwork localized in the Iron Quadrangle, Minas Gerais, Brazil. The steel slag sample was characterized by instrumental neutron activation analysis (INAA), using the TRIGA MARK I IPR-R1 nuclear research reactor. The results are compared with the characterizations made with XRD and SEM-EDS. Although XRD and EDS results indicated the presence of magnetite in a small proportion, INAA was decisive confirming the presence of REE in the mineralogical composition of the composite sample collected.
\end{abstract}

Keywords: Steel slag, REE, $\mathrm{Fe}_{3} \mathrm{O}_{4}$, INAA. 


\section{INTRODUCTION}

The extraction of iron ore and its transformation into steel is an economically important activity for Brazil and, especially for Minas Gerais state [1,2]. On the other hand, is also a source of concern regarding the consequent tailing production, being relevant to establish reuse strategies, making them economically viable by-products. The steelmaking sector is a unit of the steel industry where pig iron is transformed into steel, and that generates tons of waste called steel slag [3]. Steel slag is currently considered a by-product because it is used in the construction industry, among others [4]. Considering the amount of slag produced daily, other forms of economic use of these wastes are objects of study. In this work it is considered the possibility of extracting $\mathrm{Fe}_{3} \mathrm{O}_{4}$ and rare earth elements (REE) from steel slag. Magnetite has interesting magnetic properties and several biotechnological applications involving the use of a small fraction of the material, justifying the extraction in steelmaking residues [5]. Small fractions of this mineral may already be of interest for extraction taking into account the expressive amount of slag generated in a steel industry and the ease of separation by magnetic extraction.

Rare earth elements are found in trace amounts of materials like iron ore, and therefore they can also be present in steel slag. Most REE mines, such as Bayan Obo (China), Mountain Pass (USA), and Mount Weld (Australia), are iron/REE operations involving conventional blast, load and haul techniques, meaning these mines have a 'two in one' advantage of processing both iron ore and rare earths [6]. The separation of REE from other materials present in steel slag may not be simple, but it would be justified by its importance as a strategic material, as REE have endless applications in advanced electronics. It is also necessary to consider the large amount of steel slag generated and which, at first, would not have a technological application. In addition, rare earth mines generate a great environmental impact; including one of the most threatening impacts that are the fact the rare earth elements contain traces of radioactive isotopes [7].

To verify the viability of steel slag reuse for extraction of the $\mathrm{Fe}_{3} \mathrm{O}_{4}$ and REE, a characterization of its composition was performed. Conventional steel waste analysis techniques include X-Ray Diffraction (XRD) [8] and, Scanning Electron Microscopy (SEM) with elemental analysis by Energy Dispersive X-ray Spectrometry (EDS) [9]. However, these techniques may not be sensitive 
to the presence of small amounts of a given material of interest. In this sense, Instrumental Neutron Activation Analysis (INAA) was applied as a characterization technique capable of supporting a prospecting for reuse of steel slag for the extraction of strategic materials present in low concentrations [10]. This paper is about the characterization of a composite sample from a steel mill.

\section{MATERIALS AND METHODS}

\subsection{Material}

Steel slag samples were sampled from a yard of a steel mill localized in Iron Quadrangle, a region in Minas Gerais state, Brazil. It was produced during the steel production of Oxygen Furnace Process (BOF) by Linz-Donawitz (LD) process [11]. One composed sample, as a representative of the steel mill, was prepared mixing five samples collected at five different points in the slag pile and prepared for granulometric reduction with $0.210 \mathrm{~mm}$ sieve opening using a sieve Granutest ${ }^{\circledR}$.

\subsection{Scanning Electron Microscopy (SEM)}

The steel slag particles of the composite sample were examined on a two-sided copper tape. The analysis was performed at a SIGMA VP field emission scanning electron microscope ZEISS. Secondary Electron (SE) detector was used to obtain images from topographic contrast [12]. The system is controlled by the ESPRIT software and is capable of performing spot analyses, in-line scans and obtaining element distribution maps [13].

\subsection{X-Ray Diffraction (XRD)}

The sample was pulverized to homogeneous powder in an agate mortar. One aliquot was distributed in a sample holder, producing a flat surface on the face exposed to X-rays. The diffractogram of the sample was obtained using the diffractometer Rigaku, model DIMAX ULTIMA PLUS automatic, with theta-theta goniometer $(\theta-\theta)$ and $2 \theta / \theta$ scan with $2 \theta$ detector and copper anode, with X-ray energy beams of $8.04 \mathrm{keV}$. The powder sample was step-scanned from 4 to $80^{\circ}(2 \theta)$ in increments of $0.02^{\circ}(2 \theta)$ and $4^{\circ} 2 \theta / \mathrm{min}$ scan rate, using $\mathrm{CuK} \alpha$ radiation $(30 \mathrm{~mA}, 40$ $\mathrm{kV}$ ). Minerals were identified based on the ICDD database - International Centre for Diffraction 
Data / Joint Committee on Powder Diffraction Standards - JCPDS (Sets 01 - 58) and the use of the JADE / 09-MDI code as crystal phase identification software [14].

\subsection{Instrumental Neutron Activation Analysis (INAA)}

In this study, the elemental concentrations present in the slag composed sample were determined by instrumental neutron activation analysis by means of $k_{0}$-standardized method [15, 16]. The sample was weighed in polyethylene vials suitable to irradiation, and was irradiated with neutron flux monitors Al-(0.1\%) Au discs (6 mm in diameter and $0.2 \mathrm{~mm}$ thick), alloy IRMM530R, from Central Bureau for Nuclear Measurements, Geel, Belgium. The irradiation was for 8 hours in the carrousel of the TRIGA MARK I IPR-R1 nuclear reactor, in the irradiation channel IC-7 with $6.35 \times 10^{11} \mathrm{~cm}^{-2} \mathrm{~s}^{-1}$ average thermal neutron flux at $100 \mathrm{~kW}$ [17].

The irradiation time was enough to activate the isotopes with nuclear characteristics adequate to determine the elements besides whose radionuclides have medium and long half - lives. After irradiation, the cooling time was about one day, time enough to decay the radionuclides with shorter half-lives so that they could interfere in the gamma spectrometry. The gamma detection system was composed by a gamma detector HPGe, $25 \%$ relative efficiency. The spectra were acquired by Genie 2000 program CANBERRA and applied the HyperLab software for net peak area evaluation. The elemental concentrations were obtained by the program Kayzero for Windows ${ }^{\circledR}$ [18-20].

For quality control, the certified reference material $\mathrm{BCR}^{\circledR}{ }^{\circledR}-320 \mathrm{R}$ was analysed [21] and the performance of the laboratory was evaluated through $E_{\mathrm{n}}$-score [22] calculated to measure the agreement between the experimental result and the assigned value, taking into account the expanded uncertainty $(\mathrm{k}=2)$ of the both values. To compare the results, the criterion $\left|E_{\mathrm{n}}\right| \leq 1$ was applied, meaning that the evaluation of the performance of the method was satisfactory and if $\left|E_{\mathrm{n}}\right|>1$, the performance was unsatisfactory.

\section{RESULTS AND DISCUSSION}

SEM image was obtained to evaluate the surface texture of the particles. SEM micrograph, Figure 1, shows the diversity in particle size. The slag texture can be an important parameter for studying the presence of REE, since they appear frequently associated with clay minerals [23]. 


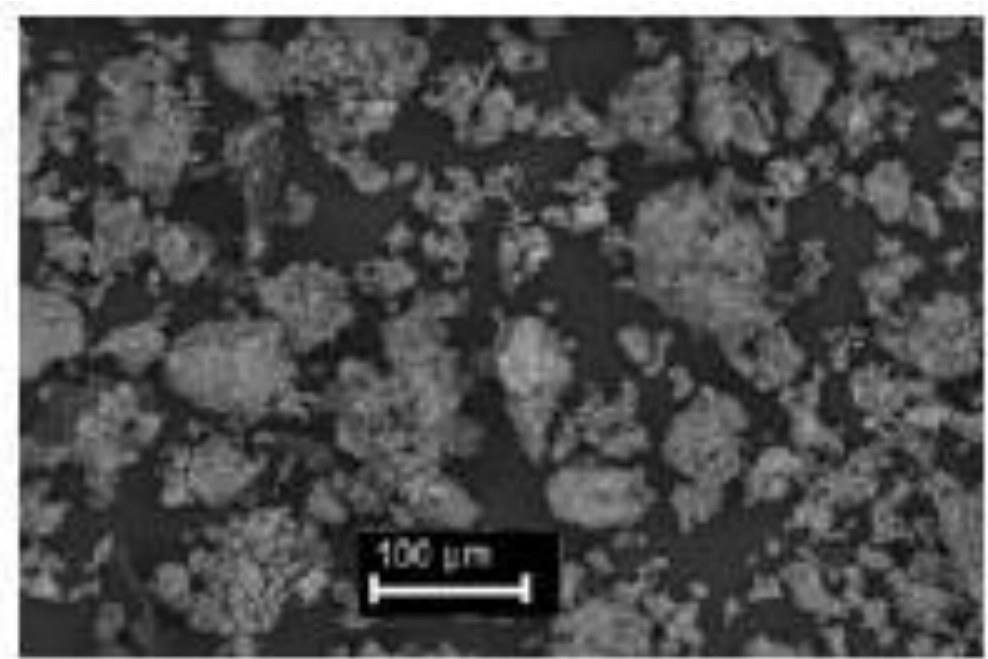

Figure 1: SEM images of the composite sample

To grasp and control the properties of steel slag and widen its application scope, it is indispensable to understand its chemical state [8]. For identifying the crystal phase, the XRD results were used and are shown in Figure 2. Table 2 shows the composition of this composite sample.

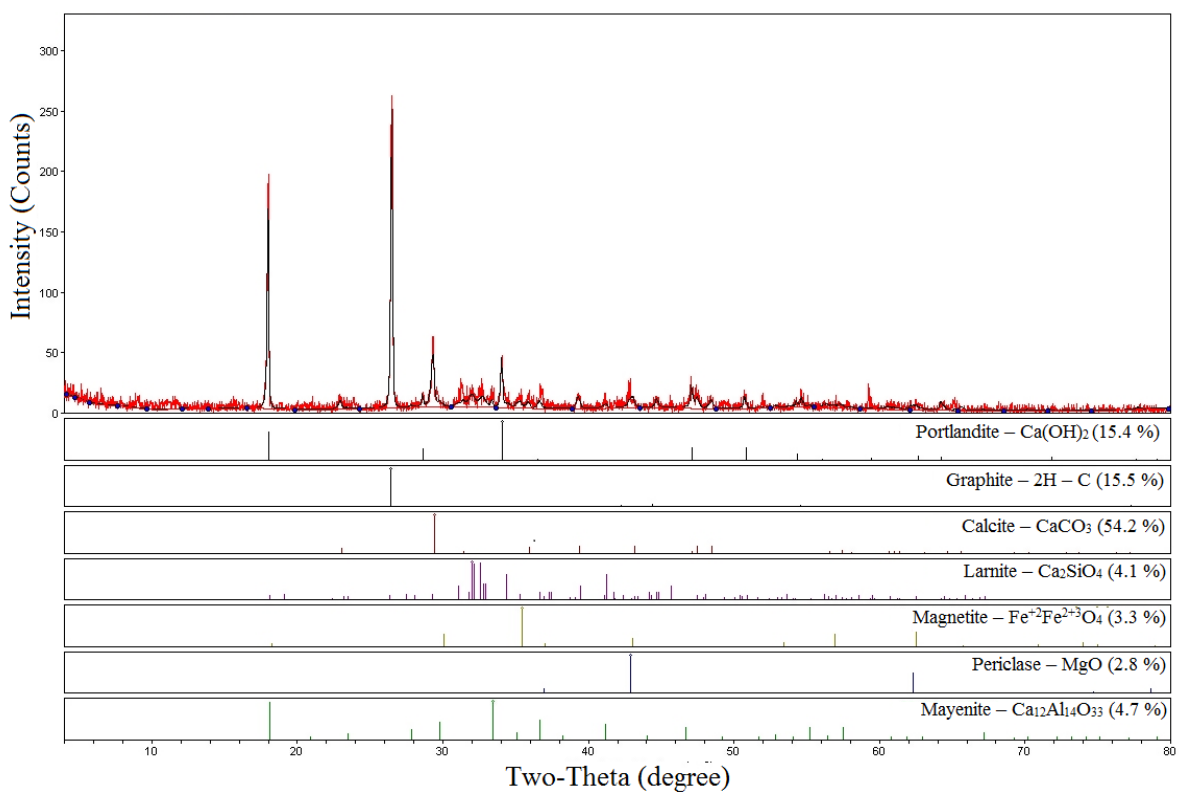

Figure 2: X-ray diffractogram of the slag sample with signalling of the characteristic peaks of the minerals identified. 
Table 2: Results for composite slag sample by X-Ray Diffraction.

\begin{tabular}{cc}
\hline Compound & Chemical composition (\%) \\
\hline $\mathrm{Ca}(\mathrm{OH})_{2}$ & 15 \\
$2 \mathrm{H}-\mathrm{C}$ & 26 \\
$\mathrm{CaCO}_{3}$ & 59 \\
$\mathrm{Fe}_{3} \mathrm{O}_{4}$ & $<5$ \\
$\mathrm{MgO}$ & $<10$ \\
$\mathrm{Ca}_{2} \mathrm{Al}_{14} \mathrm{O}_{33}$ & $<5$ \\
$\mathrm{MgSiO}_{3}$ & $<10$ \\
$\mathrm{Ca}_{11}\left(\mathrm{SiO}_{4}\right)_{4} \mathrm{O}_{2} \mathrm{~S}$ & $<20$ \\
$\mathrm{Ca}_{2} \mathrm{SiO}_{4}$ & $<15$ \\
\hline
\end{tabular}

The result obtained by the XRD technique confirms the higher proportion of limestone, that is consistent with the process of obtaining the slag [24]. The results show a large proportion of calcium in the samples due to the process of reducing iron ore. In this step, it is necessary to remove the silica, alumina $\left(\mathrm{Al}_{2} \mathrm{O}_{3}\right)$, and other non-ferrous components contained in iron ore. Limestone, a sedimentary rock composed mainly by calcite $\left(\mathrm{CaCO}_{3}\right)$, clay, sand and $\mathrm{Fe}_{3} \mathrm{O}_{4}$, is used for this. The added limestone fuses with these components and lowers their melting point, making it easier to separate them from the iron and recover them [24].

On the other hand, a higher proportion of iron could be expected, since calcium oxide and iron oxide are, in general, the two major chemical constituents of steel slags. During the conversion of molten iron into steel, a percentage of the iron in the hot metal cannot be recovered into the steel produced. This oxidized iron should be observed in the chemical composition of the steel slag [25].

Table 3 shows the certified values and experimental results for $\mathrm{BCR}^{\circledR}-320 \mathrm{R}$ and $E_{\mathrm{n}}$-score results. It is possible to observe that the evaluation of the performance of the method $k_{0}$-INAA at Laboratory for Neutron Activation Analysis-CDTN was satisfactory, $\left|E_{\mathrm{n}}\right| \leq 1$. 
Table 3: Results for $\mathrm{BCR}^{\circledR}-320 \mathrm{R}$ (Channel Sediment) and $E_{\mathrm{n}}$-score

\begin{tabular}{cccc}
\hline & \multicolumn{3}{c}{ BCR $^{\circledR}$-320R } \\
\cline { 2 - 4 } & $\begin{array}{c}\text { Experimental Results } \\
\left(\mathbf{m g ~ k g}^{-1}\right)\end{array}$ & $\begin{array}{c}\text { Certified Values } \\
\left(\mathbf{m g ~ k g}^{-1}\right)\end{array}$ & $\begin{array}{c}\boldsymbol{E}_{\mathbf{n}} \text {-score } \\
\boldsymbol{k = 2}\end{array}$ \\
\hline $\mathrm{As}$ & $23 \pm 1$ & $21.7 \pm 2.0$ & +0.27 \\
$\mathrm{Co}$ & $10 \pm 1$ & $9.7 \pm 0.6$ & +0.25 \\
$\mathrm{Cr}$ & $62 \pm 4$ & $59 \pm 4$ & +0.31 \\
$\mathrm{Fe}$ & $26083 \pm 1780$ & $25700 \pm 1300$ & +0.10 \\
$\mathrm{Sc}$ & $5.4 \pm 0.4$ & $5.2 \pm 0.4$ & +0.26 \\
$\mathrm{Se}$ & $0.8 \pm 0.1$ & $0.96 \pm 0.18$ & -0.76 \\
$\mathrm{Th}$ & $5.3 \pm 0.5$ & $5.3 \pm 0.4$ & -0.05 \\
$\mathrm{U}$ & $1.4 \pm 0.1$ & $1.56 \pm 0.20$ & -0.34 \\
\hline
\end{tabular}

Table 4 shows the results obtained by Instrumental Neutron Activation technique, $k_{0}$-method, for steel slag composite sample. It is observed that, among the 17 existing REEs, six were identified in the steel slag sample, namely: $\mathrm{Ce}, \mathrm{Eu}, \mathrm{La}, \mathrm{Nd}, \mathrm{Sc}$ and $\mathrm{Sm}$, highlighted in bold. Elements such as $\mathrm{Ce}, \mathrm{La}$ and $\mathrm{Nd}$ presenting concentrations much higher than the others is confirmed by the literature, where it is reported that the "light rare earth elements" (LREE), in their majority, have higher concentrations than the "heavy rare earth elements" (HREE) [26].

The results reinforce the characterization carried out with other analysis techniques, regarding the majority presence of calcium, which makes up the limestone observed by the XRD technique. In addition, it adds information indicating major the proportion of iron and presence of REE, also the presence of thorium in a low proportion. 
Table 3: Elemental composition of steel slag composite sample identified by INAA. $\mathrm{mg} \mathrm{kg}^{-1}$ $\%$

\begin{tabular}{|c|c|c|}
\hline \multicolumn{3}{|c|}{ Steel slag composite sample } \\
\hline \multirow{3}{*}{ Elements } & \multirow{2}{*}{\multicolumn{2}{|c|}{$\begin{array}{c}\text { Concentration } \\
\text { (Value } \pm \text { Uncertainty) }\end{array}$}} \\
\hline & & \\
\hline & $\mathrm{mg} \mathrm{kg}^{-1}$ & $\%$ \\
\hline $\mathrm{Ba}$ & $157 \pm 8$ & \\
\hline $\mathrm{Ca}$ & & $29 \pm 1$ \\
\hline $\mathrm{Ce}$ & $48 \pm 2$ & \\
\hline $\mathrm{Co}$ & $1.09 \pm 0.05$ & \\
\hline $\mathrm{Cr}$ & $387 \pm 1$ & \\
\hline $\mathbf{E u}$ & $0.26 \pm 0.02$ & \\
\hline $\mathrm{Fe}$ & & $14.4 \pm 0.5$ \\
\hline Hf & $1.06 \pm 0.04$ & \\
\hline $\mathrm{K}$ & $49 \pm 7$ & \\
\hline La & $27 \pm 1$ & \\
\hline $\mathrm{Na}$ & $115 \pm 4$ & \\
\hline Nd & $10.6 \pm 0.6$ & \\
\hline $\mathbf{S b}$ & $\mathbf{0 . 2 7} \pm \mathbf{0 . 0 3}$ & \\
\hline Sc & $1.62 \pm 0.06$ & \\
\hline Sm & $1.34 \pm 0.06$ & \\
\hline $\mathrm{Sr}$ & $1228 \pm 50$ & \\
\hline $\mathbf{T a}$ & $0.98 \pm 0.04$ & \\
\hline $\mathbf{T b}$ & $0.17 \pm 0.01$ & \\
\hline Th & $2.22 \pm 0.08$ & \\
\hline
\end{tabular}

The presence of magnetite and REE identified by the techniques indicates the possibility of reusing steel slag in addition to its use in the construction industry, indicating the potential for reuse 
in the area of technological products. Even so, it is not enough to assess the economic viability of extracting REE, since it involves technical difficulties in the chemical separation of these minerals.

\section{CONCLUSION}

Steel slags release pollutants in the environment and pose ecological problems to the surrounding ecosystem. Therefore, consideration should be given to potential slag reuse. It allows end users to gain strategic minerals that would otherwise end up trapped in the discarded waste. Even though these strategic minerals in the slags are sometimes low, the total amount recovered may yet prove to be economically profitable considering the huge volume of waste products disposed of and produced at current rates. For the reuse is necessary in principle a careful characterization, since the composition of the slag varies greatly from one steel plant to another.

In the analysis performed in this work the presence of magnetite in the slag was identified by $\mathrm{XRD}$, a material of great interest for use in applications associated with recent technological advances, focused on biotechnological use. The SEM image indicates that the slag is formed in variable textures, containing clay minerals, which may be associated with the presence of REE observed by INAA technique.

Therefore, despite the XRD and INAA techniques confirm higher proportion of limestone in steel slag, commonly used in the civil construction industry, the identification of magnetite and REE suggest the possibility of the technological reuse of the steel slag. Even so, a careful evaluation is necessary as to the economic viability for reuse of this material as a by-product or source of extraction of materials of technological interest. 


\section{ACKNOWLEDGMENT}

Financial support from Conselho Nacional de Pesquisa e Desenvolvimento Científico (CNPq) and Fundação de Amparo a Pesquisa do Estado de Minas Gerais (FAPEMIG) are acknowledged.

\section{REFERENCES}

[1] KESSLER, W.; MULLER, G. Minor and trace-element data of iron oxides from ironformations of the Iron Quadrangle, Minas Gerais, Brazil. Miner Petrol, v. 39, p. 245-250, 1988.

[2] CARVALHO FILHO, A.; INDA, A. V.; FINK, J. R.; CURI, N. Iron oxides in soils of different lithological origins in Ferriferous Quadrilateral (Minas Gerais, Brazil). Appl Clay Sci, v. 118, p. 1-7, 2015.

[3] CHAND, S.; PAUL, B.; KUMAR, M. Sustainable approaches for LD slag waste management in steel industries: a review. Metallurgist, v. 60, p. 116-128, 2016.

[4] DAS, B.; PRAKASH, S.; REDDY, P. S. R.; MISRA, V. N. An overview of utilization of slag and sludge from steel industries. Resour Conserv Recy, v. 50, p. 40-57, 2007.

[5] ZHANG, J. L.; WANG, Y.; JI, H.; WEI, Y. G.; WU, N. Z.; ZUO, B. J.; WANG, Q. L. Magnetic nanocomposite catalysts with high activity and selectivity for selective hydrogenation of orthochloronitrobenzene. J Catal, v. 229, p. 114-118, 2005.

[6] COLLIGAN, G.; COOK, C.; ERICKS, A. HOFF, R.; OLIVER, B. Iron Ore and Rare Earth Elements Market Interactions. Group: Iron Ore Diggers, 2016.

[7] DING, Y.; WANG, J.; WANG, G.; XUE, Q. Innovative Methodology for Separating of Rare Earth and Iron from Bayan Obo Complex Iron Ore. ISIJ International, v. 52, p. 1772-1777, 2012.

[8] YILDIRIM, Irem Zeynep; PREZZI, Monica. Geotechnical properties of fresh and aged basic oxygen furnace steel slag. J Mater Civil Eng, v. 27, n. 12, p. 04015046, 2015.

[9] AIMOTO, M.; KANEHASHI, K.; FUJIOKA, Y. Analytical Technologies for steel slag. Nippon Steel \& Sumitomo Metal Technical Report, v. 109, p. 16-22, 2015. 
[10] SROOR, A.; ABDEL-BASSET, N.; ABDEL-HALEEM, A. S.; HASSAN, A. M. Elemental analysis of two Egyptian iron ores and produced industrial iron samples by neutron activation analysis. Appl Radiat Isot, v. 54, n. 3, p. 559-562, 2001.

[11] AlMEIDA, E.; ASSUNÇÃO, W.; OlIVEIRA, M. F.; MAIA, B. T.; GARAJAU, F. S.; GUERRA, M. S. L.; ANDRADE, W. M.; SILVA, W. M. New BOF Performance at Gerdau Ouro Branco by Slagless ${ }^{\circledR}$ Technology. 2017.

[12] CARL ZEISS NTS. Sigma Field Emission Scanning Electron Microscope. Oberkochen, Germany, 2011. Available at: <http://www.iitk.ac.in/meesa/SEM/SEM_manual.pdf>. Last accessed: 22 June. 2020.

[13] BRUKER. ESPRIT Compact Software for QUANTAX Microanalysis Systems. Bruker Nano GmbH, Berlin, Germany, 2017. Available at: <https://www.mse.ucr.edu/sites/g/files/rcwecm1241/files/2019>. Last accessed: 22 June. 2020.

[14] JCPDS - Joint Committee on Powder Diffraction Standards. Powder Diffraction File. International Centre for Diffraction Data-ICDD, Alphabetical Indexes, Sets 1-52, Pennsylvania, 2000.

[15] DE CORTE, F. The $k_{0}$-standardization method: a move to the optimization of neutron activation analysis. 1987. 463 f. Thesis, University of Gent, Belgium, 1987.

[16] GREENBERG, R. R.; BODE, P.; FERNANDES, E. A. N. Neutron activation analysis: A primary method of measurement. Spectrochim Acta B, v. 66, p.193-241, 2011.

[17] MENEZES, M. A. B. C.; JACIMOVIC, R. Optimised $k_{0}$-instrumental neutron activation method using the TRIGA MARK I IPR-R1 reactor at CDTN/CNEN, Belo Horizonte, Brazil. Nucl Instrum Methods Phys Res A, v. 564, p. 707-715, 2006.

[18] HYPERLAB. Gamma Spectroscopy Software, HyperLabs Software. Budapest: Hyperlab, 1998-2013, 2009.

[19] SIMONITS, A.; OSTOR, J.; KALVIN, S.; FAZEKAS, B. A new concept in gamma-ray spectrum analysis. J Radioan Nucl Chem, v. 257, p. 589-595, 2003.

[20] KAYZERO FOR WINDOWS ${ }^{\circledR}$. User's Manual, for reactor neutron activation analysis (NAA) using the $\boldsymbol{k}_{\mathbf{0}}$ standardisation method, Netherlands: Kayzero, 2011. 
[21] IRMM - Institute for Reference Materials and Measurements. Certified Reference Material BCR-320R, Certificate of Analysis, mass fraction in Channel Sediment, Belgium: IRMM, 2006.

[22] ISO 13528:2005, Statistical methods for use in proficiency testing by interlaboratory comparisons, ISO, Geneve, Switzerland, 2005.

[23] DINAli, G. S.; RAIZ, R. A.; AMISTADI, M. K.; CHOROVER, J.; LOPES, G. GUILHERME, L. R. G. Rare earth elements (REY) sorption on soils of contrasting mineralogy and texture. Environ Int, v. 128, p. 279-291, 2019.

[24] POSTILA, H.; KARJALAINEN, S. M.; KLØVE, B. Can limestone, steel slag or man-made sorption materials be used to enhance phosphate-phosphorus retention in treatment wetland for peat extraction runoff with low phosphorous concentration? Ecol Eng, v. 98, p. 403-409, 2017.

[25] YILDIRIM, I. Z.; PREZZI, M. Geotechnical Properties of Fresh and Aged Basic Oxygen Furnace Steel Slag. J Mater Civ Eng, v. 27(12), p. 1-11, 2015.

[26] BATTSENGEL, A.; BATNASAN, A.; NARANKHUU, A.; HAGA, K.; WATANABE, Y.; SHIBAYAMA, A. Recovery of light and heavy rare earth elements from apatite ore using sulphuric acid leaching, solvent extraction and precipitation. Hydrometallurgy, v. 179, p. 100109, 2018. 